\title{
Purulent Discharge
}

National Cancer Institute

\section{Source}

National Cancer Institute. Purulent Discharge. NCI Thesaurus. Code C50717.

Pus-containing fluid that is draining from an orifice or wound. 